Jurnal Health Sains: p-ISSN : 2723-4339 e-ISSN : 2548-1398

Vol. 2, No. 2, Februari 2021

\title{
EFEKTIVITAS ANTI-ULCER FUKOIDAN DARI RUMPUT LAUT COKLAT SARGASSUM POLYCYSTUM
}

Vivi Asfianti dan Artha Yuliana Sianipar

Universitas Sari Mutiara Indonesia, Medan, Indonesia

Email: vivi.asfianti@yahoo.com

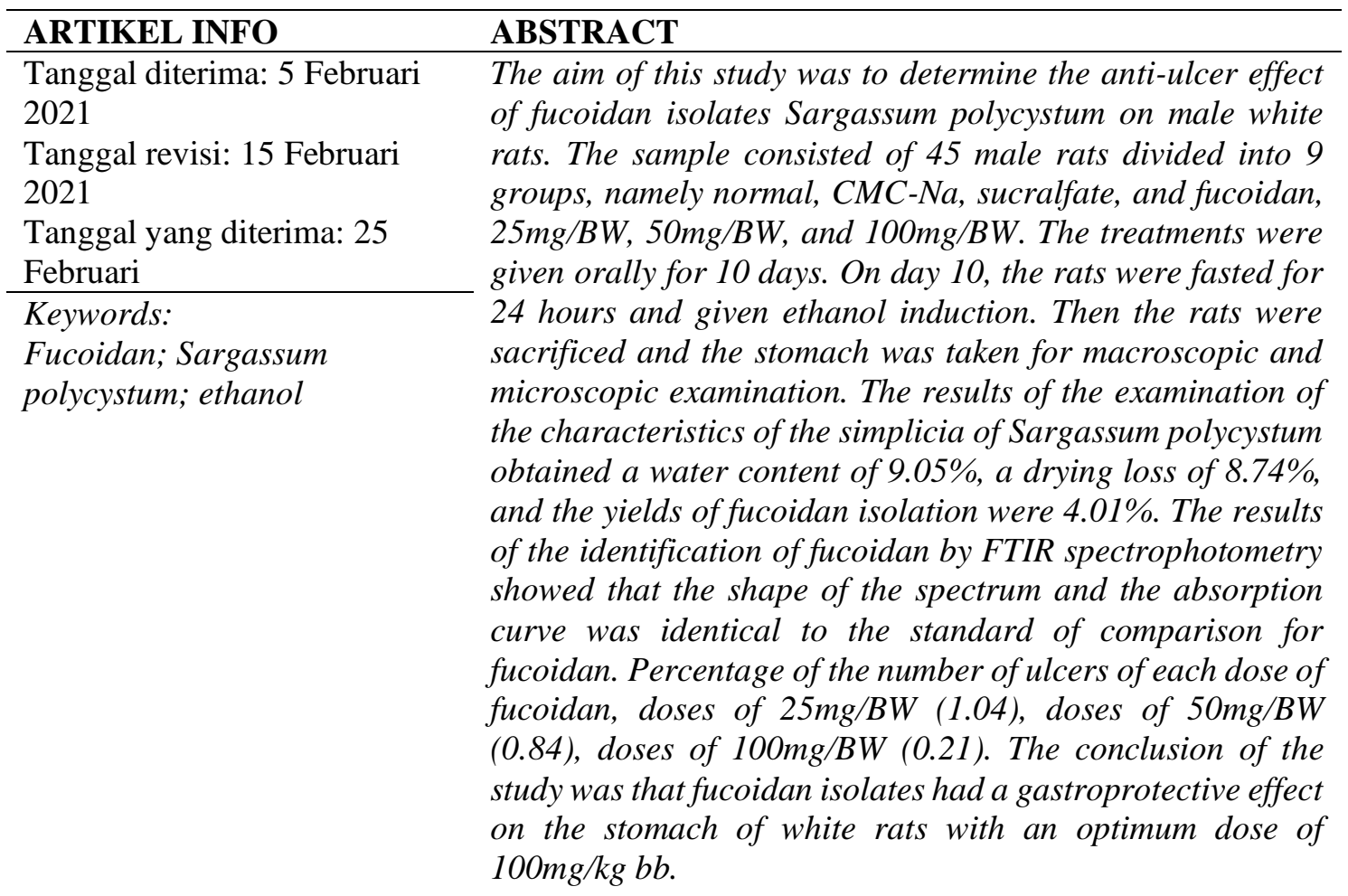

Kata Kunci:

Fukoidan, Sargassum polycystum, etanol

\begin{abstract}
ABSTRAK
Tujuan penelitian untuk mengetahui efek antiulkus isolat fukoidan dan Sargassum polycystum terhadap tikus putih jantan. Sampel terdiri dari 45 ekor tikus jantan dibagi 9 kelompok yaitu normal, CMC-Na, sukralfat, fukoidan dan $25 \mathrm{mg} / \mathrm{kgbb}, 50 \mathrm{mg} / \mathrm{kgbb}$ dan $100 \mathrm{mg} / \mathrm{kgbb}$. Perlakuan diberi per oral selama 10 hari. Pada hari ke-10, tikus dipuasakan selama 24 jam dan diberikan induksi etanol P.A. Kemudian tikus dikorbankan dan diambil lambung untuk dilakukan pemeriksaan makroskopik dan mikroskop. Hasil pemeriksaan karakteristik simplisia Sargassum polycystum diperoleh kadar air 9,05\%, susut pengeringan $8,74 \%$ dan rendemen hasil isolasi fukoidan dan adalah $4,01 \%$ dan $6,4 \%$. Hasil identifikasi fukoidan secara spektrofotometri FTIR menunjukkan bentuk spektrum dan kurva serapan identik dengan baku pembanding fukoidan. Persentase jumlah tukak masing-masing dosis fukoidan dan yaitu, dosis $25 \mathrm{mg} / \mathrm{kgbb}$ (1.04 dan 0,85$)$, dosis $50 \mathrm{mg} / \mathrm{kgbb}(0,84$ dan 0,67$)$, dosis
\end{abstract}


$100 \mathrm{mg} / \mathrm{kgbb}(0,21$ dan 0,40$)$. Kesimpulan hasil penelitian adalah isolat fukoidan dan memiliki efek gastroprotektif terhadap lambung tikus putih dengan dosis optimum $100 \mathrm{mg} / \mathrm{kgbb}$.

\section{Pendahuluan}

Tukak lambung terjadi ketika ada ketidakseimbangan antara faktor agresif (sekresi asam pepsin) dan faktor protektif (seperti sekresi lendir, pelindung mukosa, regenerasi sel, aliran darah dan prostaglandin). Berbagai faktor seperti merokok, pola makan yang buruk, alkohol, stress, infeksi (Helicobacter pylori) dan menggunakan obat non-steroidal anti-inflammatory (NSAID) dalam jangka panjang merupakan faktor penyebab tukak lambung. Berdasarkan faktor tersebut maka terdapat 2 pengobatan utama untuk tukak lambung yang pertama yaitu untuk mengurangi produksi asam lambung dan yang kedua dengan meningkatkan proteksi mukosa lambung (Choudhary et al., 2018).

Sebagai salah satu penyakit tidak menular yang dapat mengganggu kualitas hidup seseorang, ulkus lambung banyak diteliti terutama terkait dengan penatalaksanaannya. Karena persentase angka kejadian ulkus lambung di Indonesia menurut WHO cukup tinggi yakni 40,8\% (274.396 kasus dari 238.452.952 jiwa penduduk) (Kurnia, 2011), maka penatalaksanaan terapi ulkus lambung terkini harus digali dengan metode yang efektif dan efisien dengan penggunaan bahan alam sebagai sumber obat dan sebagai obat. Penelitian sebelumnya menunjukkan pemberian $1 \mathrm{~mL}$ sirup dapat menyembuhkan ulkus lambung tikus yang diinduksi dengan aspirin $400 \mathrm{mg} / \mathrm{kgbb}$ tikus (Arianto et al., 2014) dan pemberian fukoidan kepada pasien di Unit Endoskopi Rumah Sakit Cipto Mangunkusumo dapat menambah
Coresponden Author

Email:vivi.asfianti@yahoo.com Artikel dengan akses terbuka dibawah lisensi ketebalan mukus mukosa lambung pada pasien gastritis kronik (Renaldi et al., 2011).

\section{Metode Penelitian}

Alga coklat Sargassum polycystum diperoleh dari Pantai Poncan, Kota Sibolga, Propinsi Sumatera Utara. Identifikasi bahan tumbuhan dilakukan di Laboratorium Biosains dan Teknologi Tumbuhan, Institut Teknologi Sepuluh November, Surabaya (No. 002/IT.I/Biosains dan teknologi Tumbuhan/2017). Alga coklat Sargassum polycystum dikumpulkan, direndam dalam air kemudian dibersihkan dari kotoran-kotoran dan sisa karang yang melekat. Dicuci dengan air mengalir sampai bersih, ditiriskan dan ditimbang beratnya. Berat basah $12,3 \mathrm{~kg}$, bahan tumbuhan disebarkan diatas kertas lalu dikeringkan dengan cara diangin-anginkan dan dimasukkan ke dalam lemari pengering hingga kering sampai simplisia tersebut jika diremas akan hancur, ditimbang berat keringnya. Berat bahan kering adalah $1,71 \mathrm{~kg}$. Selanjutnya simplisia diblender sampai menjadi serbuk, kemudian serbuk simplisia disimpan dalam kantong plastik dan diberi silika gel.

\section{Pemeriksaan Karakteristik Simplisia}

\section{a. Pemeriksaan makroskopik}

Pemeriksaan makroskopik simplisia dilakukan terhadap bentuk "batang" dan "daun", rasa, bau dan warna simplisia.

\section{b. Penetapan kadar air}


Analisis kadar air dilakukan menurut metode gravimetri AOAC (1990), dengan mengeringkan sampel pada suhu $105^{\circ} \mathrm{C}$. Kadar air ditentukan berdasarkan berat keringnya yang merupakan persentase dari berat kering dengan berat awal (Mushollaeni, 2011).

\section{c. Isolasi Fukoidan}

Serbuk simplisia diekstraksi dengan pelarut akuades selama 4 jam. Ditimbang lebih kurang 50 gr serbuk simplisia dimasukkan kedalam gelas beker $500 \mathrm{ml}$. Ditambahkan $500 \mathrm{ml}$ akuades dan dipanaskan pada suhu $100^{\circ} \mathrm{C}$ selama 4 jam diatas hot plate yang dilengkapi termometer untuk memantau suhu tetap selama waktu ekstraksi. Setelah ekstraksi selesai, ekstrak disaring menggunakan kain flanel selagi panas. Kemudian disentrifugasi dengan kecepatan 6000 rpm selama 5 menit, filtrat ditampung dan endapan dibuang. Ditambahkan etanol 96\% sama banyak dengan filtrat hingga terbentuk endapan. Disentrifugasi kembali kecepatan $6000 \mathrm{rpm}$ selama 5 menit. Endapan diambil dengan cara enap tuangkan. Endapan yang diperoleh dikeringkan di dalam oven pada suhu $50^{\circ} \mathrm{C}$. Setelah kering serbuk fukoidan ditimbang lalu dimasukkan kedalam vial dan simpan dalam desikator (Ghosh \& Galczynski, 2014).

\section{Pemeriksaan Karakteristik Fukoidan} a. Penetapan susut pengeringan

Susut pengeringan adalah kadar bagian yang menguap dari suatu zat. Sebanyak 1 gram serbuk kering ditimbang seksama dalam botol timbang dangkal bertutup yang sebelumnya telah dipanaskan pada suhu 105 oC selama 30 menit dan telah ditara. Zat diratakan dalam botol timbang hingga merupakan lapisan setebal 5-10 $\mathrm{mm}$, dimasukkan ke dalam lemari pengering, tutupnya dibuka lalu dikeringkan pada suhu $1050 \mathrm{C}$ hingga bobot tetap. Sebelum setiap pengeringan, biarkan botol dalam keadaan tertutup mendingin dalam desikator hingga suhu kamar. Susut pengeringan dihitung tehadap bahan awal (Depkes, 2019)

b. Karakteristik Fukoidan secara Spektrofotometri FTIR

Identifikasi dilakukan dengan cara mencampurkan $1 \mathrm{mg}$ senyawa baku fukoidan ditambah $10 \mathrm{mg} \mathrm{KBr}$ digerus didalam mortir, ditekan hingga diperoleh pelet, kemudian dimasukkan ke dalam alat spektrofotometri FTIR, diukur serapannya pada frekuensi 4000-400 $\mathrm{cm}^{-1}$ (Ghosh \& Galczynski, 2014).

\section{c. Penyiapan Hewan}

Hewan uji yang digunakan adalah tikus putih jantan sebanyak 45 ekor dengan berat 180-200g. Penelitian ini dilaksanakan sesuai norma etika yang ditetapkan oleh Komite Etik Riset Kesehatan Nasional dan disetujui oleh Komite Etik Riset Kesehatan Nasional, Fakultas Matematika dan Ilmu Pengetahuan Alam, Universitas Sumatera Utara (No. 00550 / KEPH-FMIPA / 2020).

\section{d. Aktivitas Anti Ulkus}

Tikus putih jantan sebanyak 30 ekor dengan berat badan 180-200g, yang telah dipuasakan ditimbang berat badannya. Tikus dibagi per kelompok yang masing-masing kelompok terdiri dari 5 ekor tikus, kelompok tikus dan diberi perlakuan secara per oral :

Kelompok I: Normal (tidak diberikan suspensi)

Kelompok II: Suspensi Na-CMC

Kelompok III: Sukralfat 0,4mg/kgbb 
KelompokI V: Suspensi fukoidan 25 $\mathrm{mg} / \mathrm{bb}$

Kelompok V: Suspensi fukoidan $50 \mathrm{mg} / \mathrm{kgbb}$

KelompokVI: Suspensi fukoidan 100 $\mathrm{mg} / \mathrm{kgbb}$

Seluruh tikus diberi perlakuan setiap hari selama 10 hari berturutturut secara per-oral. Pada hari ke-10 setelah diberikan perlakuan tikus dipuasakan selama 24 jam, kemudian diberikan induksi etanol P.A $(99,5 \%)$ secara per-oral dengan dosis $2 \mathrm{ml} / 200$ mg dalam keadaan tikus tetap dipuasakan setelah 6 jam diberikan induksi hewan dikorbankan dengan menggunakan klorofom. Kemudian hewan dibedah dan diambil organ lambung untuk pemeriksaan makroskopik dan mikroskopik.

\section{Hasil dan Pembahasan}

Hasil karakteristik serbuk simplisia rumput laut coklat Sargassum polycystum dapat dilihat pada Tabel 1.

Tabel 1

Hasil pemeriksaan karakteristik penetapan kadar air simplisia rumput laut coklat Sargassum polycystum

\begin{tabular}{ccc}
\hline Parameter & $\begin{array}{c}\text { Hasil (\%) } \\
\text { Rata-rata }\end{array}$ & $\begin{array}{c}\text { Persyaratan } \\
\text { menurut LIPI } \\
\text { Oseanografi } \\
(\%)\end{array}$ \\
\hline $\begin{array}{c}\text { Penetapan } \\
\text { kadar air }\end{array}$ & 9,05 & $<12,37$ \\
\hline
\end{tabular}

Hasil penetapan kadar air yang diperoleh lebih kecil dari 12,37\%, hasil ini memenuhi persyaratan yang ditetapkan. Kadar air dalam simplisia menunjukkan jumlah air yang terkandung dalam simplisia tersebut, kadar air dalam simplisia berhubungan dengan proses pengeringan simplisia. Penetapan kadar air dilakukan untuk memberikan batasan kandungan air yang memenuhi persyaratan, karena kandungan air dalam simplisia merupakan salah satu faktor yang mempengaruhi aktivitas enzim dan aktivitas mikroba

Hasil isolasi senyawa fukoidan dapat dilihat pada Tabel 2.

Tabel 2

Hasil isolasi senyawa fukoidan dari rumput laut coklat Sargassum polycystum

\begin{tabular}{cccc}
\hline No & $\begin{array}{c}\text { Temperature } \\
\left({ }^{\circ} \mathrm{C}\right)\end{array}$ & $\begin{array}{c}\text { Rendemen } \\
(\%)\end{array}$ \\
\hline 1 & 4 & 100 & 4,0116 \\
\hline 2 & 4 & 100 & 4,0248 \\
\hline 3 & 4 & 100 & 4,0124 \\
\hline Rendemen $(\%)$ & & 4,0162 \\
\hline
\end{tabular}

Hasil pemeriksaan karakteristik susut pengeringan simplisia rumput laut coklat Sargassum polycystum dapat dilihat pada Tabel 3.

Tabel 3

Hasil pemeriksaan karakteristik susut pengeringan simplisia rumput laut coklat Sargassum polycystum

\begin{tabular}{cc}
\hline Parameter & $\begin{array}{c}\text { Hasil (\%) } \\
\text { Rata-rata }\end{array}$ \\
\hline $\begin{array}{c}\text { Penetapan susut } \\
\text { pengeringan }\end{array}$ & $\mathbf{8 , 7 4}$ \\
\hline
\end{tabular}

Tujuan dari pengeringan adalah mengurangi kandungan air dalam Sargassum, karena kualitas kandungan dalam Sargassum semakin baik dengan semakin rendah kadar airnya (Hidayat et al., 2004). Proses pengeringan yang kurang tepat akan mengakibatkan beberapa kerugian, yaitu sifat bahan asal yang dikeringkan dapat berubah, misalnya bentuk dan kenampakan, dan sifat mutu. Pengeringan ini akan berpengaruh terhadap senyawa penting yang terkandung dalam Sargassum polycystum tersebut. Pengeringan Sargassum polycystum yang benar maka akan menghasilkan senyawa aktif yang nantinya dapat digunakan lebih lanjut (Istadi \& Sitompul, 2002). Hasil ratarata penetapan susut pengeringan senyawa fukoidan rumput laut coklat Sargassum polycystum yaitu $8,74 \%$. 
Penentuan gugus fungsi fukoidan dilakukan dengan spektrofotometri digunakan untuk senyawa murni yang dapat diidentifikasi, dapat membandingkan spektrum inframerah sampel dengan spektrum inframerah pembanding (Kurnia et al., 2018). Spektrum inframerah hasil isolasi dapat dilihat pada gambar 1 .

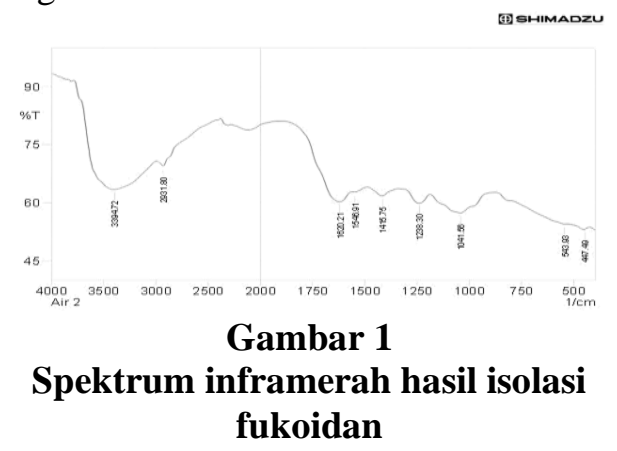

Data spektrum inframerah hasil isolasi fukoidan dapat dilihat pada Tabel 4.

Tabel 4

Data Spektrum Inframerah Fukoidan Hasil Isolasi Dan Baku Pembanding Fukoidan

\begin{tabular}{|c|c|c|}
\hline \multicolumn{2}{|c|}{ Panjang Gelombang $\left(\mathrm{cm}^{-1}\right)$} & \multirow[b]{2}{*}{ TipeVibrasi } \\
\hline $\begin{array}{l}\text { Isolasi } \\
\text { Fukoidan }\end{array}$ & $\begin{array}{c}\text { Baku } \\
\text { Pembanding } \\
\text { Fukoidan }\end{array}$ & \\
\hline 3394,72 & 3421,72 & $\begin{array}{c}\text { Hydroxyl } \\
\text { group (O- } \\
\mathrm{H})\end{array}$ \\
\hline 2931,8 & 2935,66 & $\begin{array}{l}\text { Alifatis C- } \\
\text { H Group }\end{array}$ \\
\hline 1620,21 & 1627,92 & $\begin{array}{l}\text { Carbonyl } \\
\text { group } \\
(\mathrm{C}=\mathrm{O})\end{array}$ \\
\hline 1415,75 & 1408,04 & $\begin{array}{l}\text { C-O-H } \\
\text { Cluster }\end{array}$ \\
\hline 1238,30 & 1242,16 & $\mathrm{CH}_{3}$ Cluster \\
\hline 1041,56 & 1134,14 & $\begin{array}{l}\text { Cluster C- } \\
\mathrm{O}\end{array}$ \\
\hline
\end{tabular}

Spektrum baku pembanding fukoidan menunjukkan serapan pada daerah 3421,72 $\mathrm{cm}^{-1}$ untuk O-H, serapan pada daerah 2935,66 $\mathrm{cm}^{-1}$ untuk $\mathrm{C}-\mathrm{H}$ alifatis, serapan pada daerah $1627,92 \mathrm{~cm}^{-1}$ untuk $\mathrm{C}=\mathrm{O}$, serapan pada daerah $1408,04 \mathrm{~cm}^{-1}$ untuk daerah C-O-H, serapan pada daerah 1242,16 $\mathrm{cm}^{-1}$ untuk $\mathrm{CH}_{3}$, dan serapan pada daerah $1134,14 \mathrm{~cm}^{-1}$ untuk C-O. Berdasarkan data diatas, dapat dilihat hasil isolasi fukoidan dan baku pembanding mempunyai gugus fungsi yang identik.

\section{Aktivitas Anti Ulkus}

Dalam penelitian ini perlakuan dibagi menjadi sembilan kelompok yaitu kelompok kontrol negatif dengan suspensi Na-CMC 1\%, kelompok perlakuan fucoidan dan dengan tiga variasi konsentrasi $(25,50$, dan $100 \mathrm{mg} /$ $\mathrm{kg}$ BB), dan kontrol positif. kelompok dengan sukralfat $0,4 \mathrm{mg} / \mathrm{kg}$ BB.

Hewan uji diinduksi dengan etanol pro analisis untuk merusak mukosa lambung. Pemberian etanol berlebihan dapat secara langsung merusak mukosa lambung melalui difusi ke dalam mukosa lambung (Amirshahrokhi \& Khalili, 2015). Etanol adalah agen ulcerogenik yang menghasilkan erosi, peradangan, dan perdarahan pada lapisan mukosa lambung (Lu et al., 2017).

Seluruh tikus diberi dosis fukoidan dan setiap hari selama 10 hari berturutturut secara per-oral. Pada hari ke-10 setelah diberikan perlakuan tikus dipuasakan selama 24 jam, kemudian diberikan induksi etanol P.A $(99,5 \%)$ secara per-oral dengan dosis $2 \mathrm{ml} / 200 \mathrm{mg}$ dalam keadaan tikus tetap dipuasakan setelah 6 jam diberikan induksi hewan dikorbankan dengan menggunakan klorofom. Tikus yang telah dibedah kemudian diisolasi lambungnya dan dibuka dengan pembedahan pada kurvatura mayor untuk selanjutnya dibersihkan dengan larutan Nacl 0,9\% lalu dibentangkan pada permukaan datar dan diamati luka yang terbentuk (Gusdinar et al., 2009).

Hasil uji fukoidan dan dapat dilihat pada Tabel 5 .

Tabel 5 


\begin{tabular}{|c|c|c|c|c|c|c|}
\hline \multirow[t]{2}{*}{$\overline{\text { No }}$} & \multirow[t]{2}{*}{ Kelompok } & \multicolumn{5}{|c|}{ Perlakuan } \\
\hline & & 1 & 2 & 3 & 4 & 5 \\
\hline 1 & Normal & 0 & 0 & 0 & 0 & 0 \\
\hline 2 & $\mathrm{Na}-\mathrm{CMC}$ & 0,83 & 0,85 & 0,85 & 0,76 & 0,83 \\
\hline 3 & Sucralfate & 0,41 & 0,39 & 0,42 & 0,41 & 0,42 \\
\hline 4 & $\begin{array}{l}\text { Fukoidan } \\
\text { Suspensi } \\
25 \mathrm{mg} / \mathrm{kg} \mathrm{BB}\end{array}$ & 1,04 & 1,05 & 1,04 & 1,03 & 1,04 \\
\hline 5 & $\begin{array}{l}\text { Fukoidan } \\
\text { Suspensi } \\
\text { 50mg/kg BB }\end{array}$ & 0,70 & 0,41 & 0,69 & 0,72 & 0,63 \\
\hline 6 & $\begin{array}{l}\text { Fukoidan } \\
\text { Suspensi } \\
100 \mathrm{mg} / \mathrm{kg} \mathrm{BB}\end{array}$ & 0,21 & 0,22 & 0,21 & 0,21 & 0,20 \\
\hline
\end{tabular}

Pengamatan kelompok perlakuan fukoidan dengan tiga konsentrasi $(25,50$, dan $100 \mathrm{mg} / \mathrm{kgBB}$ ) pada hewan uji aktivitas anti ulkus. Polisakarida sulfat yang dapat mempercepat penyembuhan ulkus yang diinduksi dengan etanol dengan meningkatkan level Prostaglandin E2 (PGE2), serta meningkatkan Nitrit Oxide yang bersifat vasodilator sehingga memperlebar pembuluh darah meningkatkan sekresi mukosa dilambung, fukoidan juga memiliki efek sitoprotektor yakni dengan cara menghibisi pepsin dan asam lambung dalam mengiritasi mukosa lambung dari histologi penelitian ini. Selain itu diketahui beberapa jenis polisakarida memiliki berat molekul yang tinggi sehingga sukar diserap tubuh seperti selulosa atau serat namun beberapa polisakarida memiliki berat molekul yang rendah seperti heparin (Amaral et al., 2012). Berdasarkan tabel di atas dapat disimpulkan bahwa secara teoritis yang memberikan skor ulkus tertinggi adalah kelompok Na-CMC sedang dengan skor terendah adalah kelompok kontrol / pembanding positif. Hal ini membuktikan bahwa obat pembanding masih menunjukkan efek yang lebih baik dibandingkan dengan isolat, begitu juga dengan isolat fukoidan yang memiliki efek kuratif. Berdasarkan tabel isolate fukoidan dan dengan dosis $100 \mathrm{mg} / \mathrm{kgBB}$ memiliki efek terapeutik yang paling baik jika dibandingkan dengan dosis lainnya.

\section{Kesimpulan}

Kesimpulan dari penelitian ini adalah hasil identifikasi fukoidan secara spektrofotometri FTIR menunjukkan bentuk spektrum dan kurva serapan identik dengan baku pembanding fukoidan dimana hal ini menunjukkan hasil isolasi dari rumput laut coklat Sargassum polycystum mengandung fukoidan serta isolat fukoidan dan memiliki efek gastroprotektif pada lambung tikus putih dengan dosis $100 \mathrm{mg} / \mathrm{kgBB}$.

\section{BIBLIOGRAFI}

Amaral, M. J., Bicho, R. C., Carretero, M. A., Sanchez-Hernandez, J. C., Faustino, A. M. R., Soares, A. M. V. M., \& Mann, R. M. (2012). The Use Of A Lacertid Lizard As A Model For Reptile Ecotoxicology Studies: Part 2-Biomarkers Of Exposure And Toxicity Among Pesticide Exposed Lizards. Chemosphere, 87(7), 765-774.

Amirshahrokhi, K., \& Khalili, A.-R. (2015). The Effect Of Thalidomide On EthanolInduced Gastric Mucosal Damage In Mice: Involvement Of Inflammatory Cytokines And Nitric Oxide. ChemicoBiological Interactions, 225, 63-69.

Arianto, A., Bangun, H., Harahap, U., \& Ilyas, S. (2014). The Comparison Of Swelling, Mucoadhesive, And Release Of Ranitidine From Spherical Matrices Of e, Chitosan, e-Chitosan, And Calcium eChitosan. International Journal Of Pharmtech Research, 6, 2054-2063.

Bpom, R. I. (2005). Standarisasi Ekstrak Tumbuhan Obat Indonesia Salah Satu Tahapan Penting Dalam Pengembangan Obat Asli Indonesia. Info Pom, 6(4), 112.

Choudhary, S., Ramasundaram, P., Dziopa, E., Mannion, C., Kissin, Y., Tricoli, L., Albanese, C., Lee, W., \& Zilberberg, J. 
(2018). Human Ex Vivo 3d Bone Model Recapitulates Osteocyte Response To Metastatic Prostate Cancer. Scientific Reports, 8(1), 1-12.

Depkes, R. (2019). Rencana Pembangunan Jangka Panjang Bidang Kesehatan 2005-2025. Dep Kes Ri.

Ghosh, R., \& Galczynski, M. (2014). Redefining Multicultural Education: Inclusion And The Right To Be Different. Canadian Scholars' Press.

Gusdinar, T., Herowati, R., Kartasasmita, R. E., \& Adnyana, I. K. (2009). Sintesis Kuersetin Terklorinasi Dan Aktivitas Perlindungan Terhadap Tukak Lambung. Majalah Farmasi Indonesia, 20(4), 171177.

Hidayat, B., Thabrany, H., Dong, H., \& Sauerborn, R. (2004). The Effects Of Mandatory Health Insurance On Equity In Access To Outpatient Care In Indonesia. Health Policy And Planning, 19(5), 322-335.

Istadi, I., \& Sitompul, J. P. (2002). A Comprehensive Mathematical And Numerical Modeling Of Deep-Bed Grain Drying. Drying Technology, 20(6), 1123-1142.
Kurnia, D., Yuliantini, A., \& Faizal, D. (2018). Pengembangan Metode Penentuan Kadar Neotam Dalam Sediaan Obat Dengan Spektrofotometri Uv. Educhemia (Jurnal Kimia Dan Pendidikan), 3(1), 66-76.

Lu, C., Meng, S., Jin, Y., Zhang, W., Li, Z., Wang, F., Wang - Johanning, F., Wei, Y., Liu, H., \& Tu, H. (2017). A Novel Multi - Epitope Vaccine From Mmsa - 1 And Dkk 1 For Multiple Myeloma Immunotherapy. British Journal of Haematology, 178(3), 413-426.

Mushollaeni, W. (2011). The Physicochemical Characteristics Of Sodium e From Indonesian Brown Seaweeds. African Journal Of Food Science, 5(6), 349-352.

Renaldi, K., Simadibrata, M., Syam, A. F., Rani, A. A., \& Krisnuhoni, E. (2011). Influence Of Fucoidan In Mucus Thickness Of Gastric Mucosa In Patients With Chronic Gastritis. The Indonesian Journal of Gastroenterology, Hepatology, And Digestive Endoscopy, 12(2), 79-84. 